\title{
Traditional wheat breeder fights for funding
}

\section{Rex Dalton, San Diego}

A prominent wheat breeder at a major US public university has narrowly retained funding for his work, after fighting off what supporters describe as a concerted effort by commercial seed suppliers to get it cut.

Stephen Jones, a plant geneticist at Washington State University (WSU) in Pullman, refuses to participate in industry-funded projects, and has spoken out publicly against what he sees as corporate efforts to gain control of wheat farming through biotechnology.

Many wheat farmers use their own seed, held over from the previous year's crop (a practice largely dropped by farmers of other crops, including corn and soya beans). Jones uses traditional breeding methods to produce more disease-resistant varieties of winter wheat that can be used in this way.

In March, some farmers - encouraged by local seed suppliers, according to several growers and officials - started a campaign to get Jones's core funding of some $\$ 200,000$ a year cut. They wanted money spent on projects that would involve commercial partners and develop crops containing patented genetic mutations. If a seed contains a patented trait it can't be legally replanted.

Jones claims that some farmers were misled. "They didn't realize that they would be destroying the public winter-wheat breeding programme at WSU," he says.
After weeks of political manoeuvring, the Washington Wheat Commission, which helps to fund WSU research programmes, voted last month to underwrite Jones's studies for the next year. The board of the Washington Association of Wheat Growers, a 3,000-member group that strongly influences the commission, voted six to five in favour of Jones's research.

Some growers, who didn't want to be identified, said the fight reflected anxieties among farmers, who want to produce wheat that is competitively priced but that will be saleable in parts of the world where transgenic varieties aren't acceptable to consumers.

Many farmers remain sceptical about the transgenic wheat being prepared for the market by large suppliers such as Monsanto. They want competitive, non-transgenic varieties based on patented genetic mutations. "Wheat growers are desperate to make ends meet," says grower James Moore, a former Wheat Commission member from Kahlotus in eastern Washington. "But the idea of cutting the wheat-breeding research programme is beyond belief. It's the only thing that will save the wheat industry."

Ralph Cavalieri, associate dean of the WSU College of Agriculture and Home Economics where Jones works, says Jones will continue his research, alongside a new industry-assisted programme. The pro-

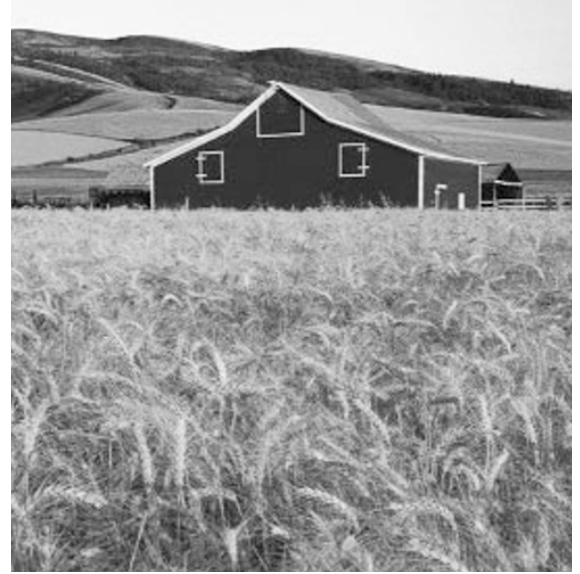

Gold reserve: many farmers save seed to replant.

gramme will involve a private company, Pullman-based Northwest Plant Breeding, and will seek to develop a new winter wheat containing a herbicide-resistant trait called Clearfield, owned by seed firm BASF.

But Cavalieri remains worried about the future of publicly funded plant breeding (see Nature 421, 568-570; 2003). "As public support of universities such as ours diminishes, our ability to provide research in the public domain declines," he says. "I have concerns about the sustainability of these public breeding programmes."

\section{German reform plan arouses fears for autonomy}

\section{Quirin Schiermeier, Munich}

German scientists and research managers are up in arms over a plan to overhaul laboratory and university funding.

The plan, to shift responsibilities between federal government and Germany's 16 Länder (states), could threaten the autonomy of basic research institutions, critics claim.

Germany's postwar constitution,

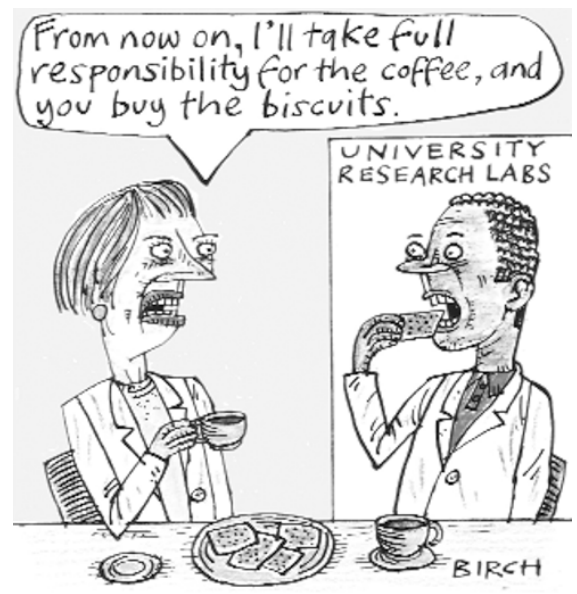

designed to avoid the concentration of power, split many responsibilities between federal government and Länder. Support of research laboratories, agencies and universities is split evenly between the two.

But under a government-wide reform programme set out last month, federal government would take sole responsibility for the 80 labs and institutes operated by the Max Planck Society (MPS) and for the DFG, Germany's main granting agency.

The Länder would maintain universities and 80 research institutes, museums and libraries operated by the Leibniz Association. Research minister Edelgard Bulmahn says that centralized financing would streamline decision-making.

And some observers recognize the need for change. "Germany's extreme federalism can indeed be obstructive," says Ulrich Herbert, a historian at the University of Freiburg, and a member of the Wissenschaftsrat, Germany's independent science council. "Untangling responsibilities could be a good thing", he adds, "but not if the federal government takes the pick of the bunch, and gives the Länder what's left."

MPS president Peter Gruss opposes the change, saying: "Before you replace a tried and tested system you should provide proof" of the substitute's superiority. Ernst-Ludwig Winnacker, president of the DFG, says that the "checks and balances" of the federal system underpin researchers' freedom from political interference.

The government and Länder must agree by the autumn, when Chancellor Gerhard Schröder wants to launch the reforms. He will start talks with state prime ministers later this month, and amendments to the proposal are likely.

Meanwhile, Germany's budget crisis, fuelling the reforms, is also hitting research directly. At the MPS's annual assembly in Hamburg on 5 June, Gruss announced a list of 13 research departments that would be closed by 2007, including departments at the MPS institutes of physics and quantum optics in Munich, experimental medicine in Göttingen, and radioastronomy in Bonn. The planned expansion of nine other institutes will also be dropped. 